\title{
Synchronous isolated ipsilateral salivary gland metastasis from a primary breast cancer - A case report
}

\author{
Ashmitha Srinivasan* \\ Department of Diagnostic Radiology, University of Texas, MD Anderson Cancer Center, United States
}

Received: October 11, 2016

DOI: $10.5430 /$ jst.v7n1p16
Accepted: November 3, $2016 \quad$ Online Published: November 8, 2016

URL: http://dx.doi.org/10.5430/jst.v7n1p16

\begin{abstract}
The most common sites of distant metastasis for breast are the lungs, liver, bones and brain. Here we report an extremely rare presentation of isolated salivary gland metastasis from primary breast cancer, indicating advanced stage of breast disease and sign of poor prognosis. The case emphasizes the need for a thorough workup for distant metastatic disease in patients diagnosed with invasive breast cancer.
\end{abstract}

Key Words: Breast cancer, Salivary gland tumor

\section{INTRODUCTION}

Most cancer-related deaths result from metastasis of tumor cells to other organs. Tumor cells can be carried to other organs directly through the bloodstream or indirectly via the lymphatic channels. For many carcinomas, including breast carcinomas, the lymphatic system is the most common route of metastatic disease. The most common sites of metastasis from breast carcinomas are the axillary lymph nodes, lungs, liver, bones, and brain. When only the axillary nodes are involved, the regional spread is still considered to be at a relatively early stage. ${ }^{[1]}$ However, when there is distant metastasis, the patient's prognosis declines significantly. Here we report an extremely rare presentation of salivary gland metastasis of invasive breast cancer, which is considered as a manifestation of an advanced stage of breast carcinoma with average survival of 6-9 months after diagnosis. ${ }^{[2-4]}$

\section{Case presentation}

A 48-year-old woman presented with 10-month history of palpable right breast lump. She had a history of negative mammogram approximately two years ago. Clinical exam confirmed palpable right breast mass in upper outer quadrant. Subsequently, she underwent diagnostic mammography and breast ultrasonography at a nearby women's health clinic. The imaging findings revealed a $3 \mathrm{~cm}$ irregular mass in the upper, outer quadrant of the right breast, highly suggestive of malignancy, categorizing it as BI-RADS 5. The patient then proceeded to have an ultrasound-guided, percutaneous needle biopsy for tissue diagnosis. Pathological analysis of the biopsy specimen revealed invasive ductal carcinoma, intermediate grade, positive for both estrogen receptor and progesterone receptor expression with more than $90 \%$ concordance, and negative for HER2/neu expression. Patient was then recommended to have consultation with surgery and oncology.

\footnotetext{
*Correspondence: Ashmitha Srinivasan, Assistant Professor; Email: asrinivasan@mdanderson.org; Address: Department of Diagnostic Radiology, University of Texas, MD Anderson Cancer Center, United States.
} 
During the surgical consultation, repeat physical examination ing and nipple retraction. In addition, there was concern for showed the palpable mass in the upper, outer quadrant of the a non-mobile, preauricular mass measuring approximately right breast with asymmetric right periareolar skin thicken- $1 \mathrm{~cm}$ in diameter.

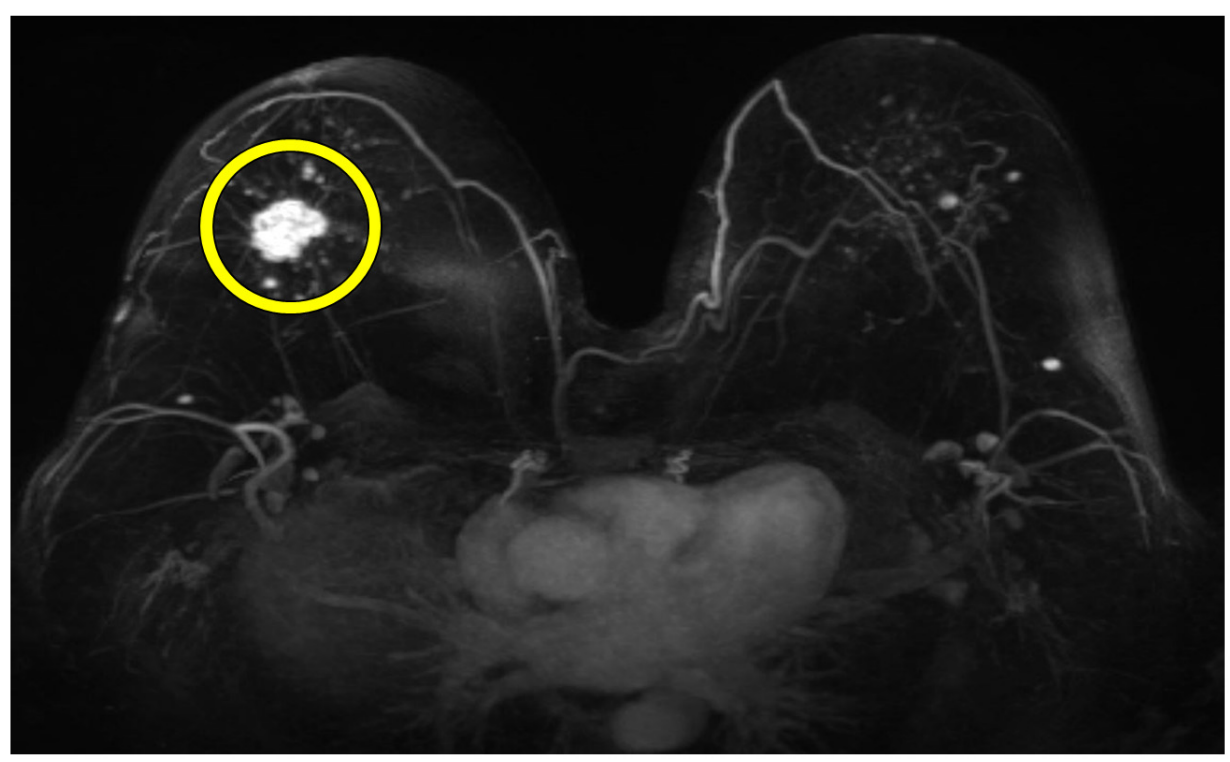

Figure 1. Post contrast axial maximum intensity projection image of the breasts demonstrates the enhancing carcinoma (circle) in the patient's right breast

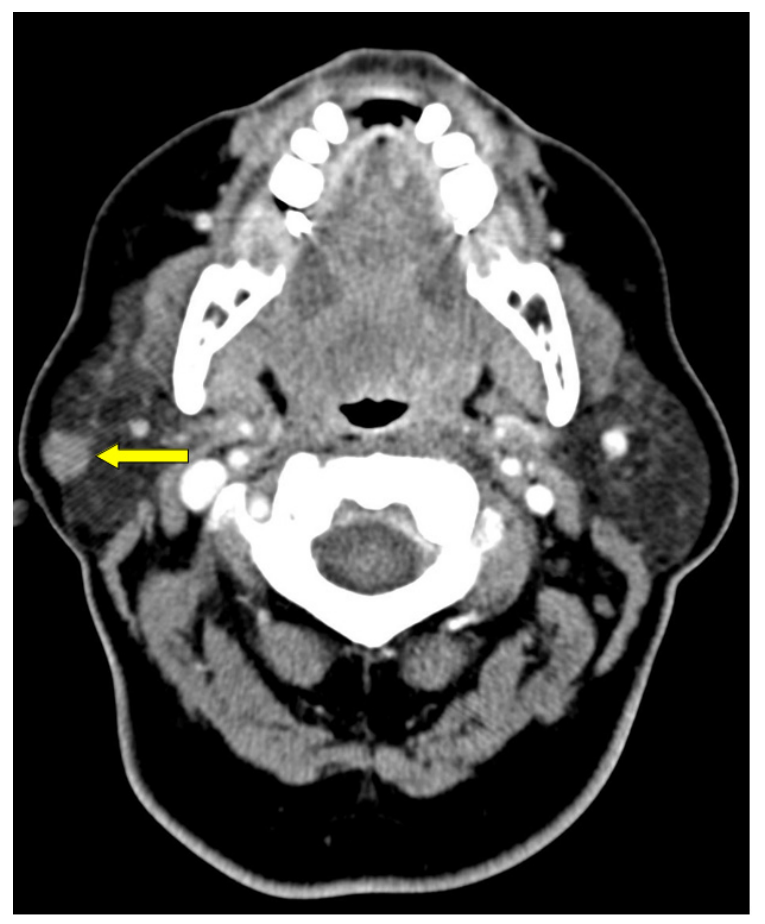

Figure 2. Axial post contrast computed tomography image demonstrates the nonspecific, enhancing soft tissue mass (arrow) in the right parotid gland

To further evaluate the extent of the right breast disease, a magnetic resonance imaging scan of the breast was ordered (see Figure 1). Consequently, the patient had a consultaPublished by Sciedu Press tion with an otolaryngologist, and a computed tomography (CT) scan of the neck was performed for evaluation of the preauricular mass (see Figures 2 and 3).

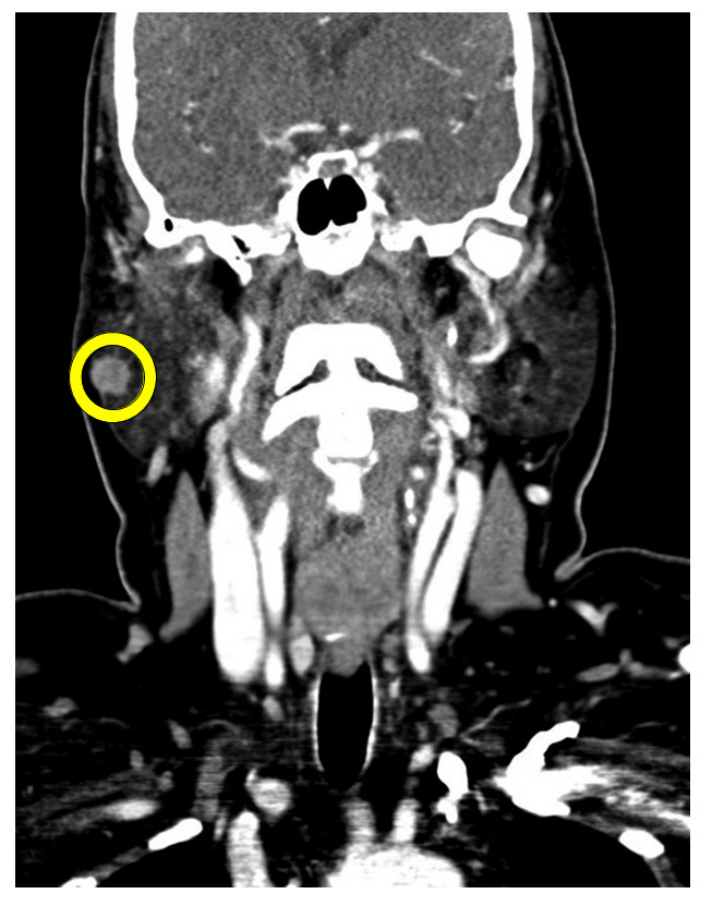

Figure 3. Coronal post contrast computed tomography image demonstrates the enhancing soft tissue mass (circle) in the right parotid gland 
The patient then underwent fine-needle aspiration (FNA) of the right parotid mass, and cytopathological analysis of the biopsy specimen showed atypical cells.

In summary, patient had biopsy proven invasive carcinoma of the right breast with clinical suspicion for right nipple involvement and biopsy proven atypical cells within the right parotid gland. The patient chose to undergo right mastectomy combined with superficial parotidectomy.

The postoperative pathological analysis of the parotid tumor revealed metastatic breast carcinoma with clear margins of resection. The diameters of the parotid and right breast tumors were about $1.5 \mathrm{~cm}$ and $3.5 \mathrm{~cm}$, respectively, and presence of 4 satellite breast tumors ranging in size from $0.3 \mathrm{~cm}$ to $0.5 \mathrm{~cm}$ in diameter. The final pathologic stage proved to be $\mathrm{T} 2 \mathrm{~N} 0$ M1. The patient decided to undergo adjuvant radiotherapy, chemotherapy and anti-hormonal therapy.

\section{DisCUSSION}

The parotid gland is the largest major salivary gland and the only one to contain intraglandular lymph nodes. Metastatic disease accounts for $9 \%$ to $14 \%$ of all parotid tumors. ${ }^{[5]}$ Metastatic disease to the parotid gland is usually caused by squamous cell carcinoma of the head and neck, primarily by direct contiguous invasion. ${ }^{[6,7]}$ On the other hand, parotid metastatic disease originating from distant infraclavicular sites is rare; tumor cells from such sites are thought to reach the parotid gland through the thoracic duct or the paraspinal venous plexus. ${ }^{[8]}$

The majority of parotid metastasis from breast cancer reported in the literature originate from invasive ductal carcinoma. ${ }^{[9]}$ In 2000, Joyce et al. reported the first documented case of breast cancer metastasizing to the parotid gland in a male patient. ${ }^{[10]}$ Very few cases have been described in which the parotid was the only or major site of breast metastasis. ${ }^{[2]}$ Involvement of both contralateral and ipsilateral salivary glands has been reported and indicates a likelihood of a hematogenous rather than lymphatic route for tumoral spread to the salivary gland region. ${ }^{[11,12]}$ Duncan et al. reported a case of metastases to both parotid glands from carcinoma of the breast that presented 25 years after initial treatment. ${ }^{[13]}$ Cihan et al. reported rare instance where the patient had synchronous involvement of both the parotid and thyroid gland. ${ }^{[4]}$ Zhang et al. reported the first case of metastatic phyllodes tumor to the parotid gland. ${ }^{[14]}$

It is important to recognize that one cannot distinguish a primary malignant tumor of the parotid from a metastasis by imaging alone and that such distinction requires FNA biopsy. FNA biopsy has an $85 \%$ accuracy rate in distinguishing be- tween malignant and benign lesions of the parotid and can differentiate primary neoplasms of the parotid from metastatic disease ${ }^{[15]}$ However, metastatic spread from breast cancer can pose a diagnostic challenge for the cytologist, as primary salivary duct carcinoma and metastatic ductal carcinoma from the breast share many morphological and immunocytochemical characteristics. The challenge posed by these similarities illustrates the importance of communicating the patient's clinical history to the pathologist. For example, primary salivary duct carcinoma mainly affects elderly men, and its occurrence as a metachronous or synchronous tumor with ductal carcinoma of the breast is unlikely and rarely described in the literature. ${ }^{[8]}$ When metastatic carcinoma is identified by parotid FNA biopsy, restaging with [18F]fluorodeoxyglucose positron emission tomography-CT scan is recommended to evaluate locoregional and look for distant disease. ${ }^{[16]}$ Treatment planning is then based on radiological staging.

The management of an isolated parotid metastasis of breast origin remains controversial, but treatment involves combination of surgery, chemotherapy and radiation therapy, with many experts favoring adjuvant radiotherapy over adjuvant chemotherapy. In our patient and in the previously reported cases, superficial parotidectomy has been successful in providing local control. ${ }^{[17]}$ From the limited cases that have been reported, parotid surgery does not seem to improve life expectancy, and the management of a parotid metastasis is considered to be palliative, regardless of the treatment method. ${ }^{[18]}$ The prognoses of these patients are often dismal, with a 5 -year survival rate of only $10 \% .{ }^{[8]}$

\section{Conclusion}

Patients diagnosed with invasive breast carcinoma should have a through metastatic workup, regardless of the status of local nodal basins. Such workup should include a comprehensive physical exam, and any suspicious findings should be evaluated by an appropriate imaging modality to guide further diagnostic workup. When extent of disease workup reveals a preauricular tumor, the possibility of a coexisting primary neoplasm of the salivary gland, benign or malignant, should be investigated by tissue biopsy. Superficial parotidectomy, adjuvant radiotherapy and anti-hormonal therapy are the preferred approach when the parotid is the only site of metastasis from breast carcinoma, although this treatment is usually done for palliative reasons.

\section{CONFLICTS OF INTEREST DisClosure}

The authors declare that there is no conflict of interest statement. 


\section{REFERENCES}

[1] Rahman M, Mohammed S. Breast cancer metastasis and the lymphatic system. Oncology Lett. 2015; 10: 1233-9. http://dx.doi .org/10.3892/ol.2015.3486

[2] Bissett D, Bessell EM, Bradley PJ, et al. Parotid metastases from carcinoma of the breast. Clin Radiol. 1989; 40: 309-10. http: //dx.doi.org/10.1016/S0009-9260(89)80218-1

[3] Herrmann JB, Adair FE. Unusual Metastatic Manifestations of Breast Carcinoma: Metastatic involvement of Preauricular Lymph Nodes and Parotid Gland. A Report of Five Cases. Ann Surg. 1949 Jan; 129(1): 137-41. PMid:17859282. http://dx.doi.org/10.1097 /00000658-194901000-00016

[4] Cihan YB, Deniz K, Yilmaz MS. Synchronous Parotid and Thyroid Gland Metastases from Breast Cancer. Breast Care (Basel). 2011; 6(2): 133-5. PMid:21673825. http://dx.doi.org/10.1159/0 00327508

[5] Laforga JB, Gasent JM. Mammary invasive duct carcinoma metastatic to parotid gland: report of a case diagnosed by fine-needle aspiration. Diagn Cytopathol. 2009; 37: 154-8. PMid:19030187. http://dx.doi.org/10.1002/dc. 21010

[6] Nuyens M, Schüpbach J, Stauffer E, et al. Metastatic disease to the parotid gland. Otolaryngol Head Neck Surg. 2006; 135: 844-8. PMid:17141071.http://dx.doi.org/10.1016/j.otohn s. 2006.05 .010

[7] Schoneveld JM, Hesp WL, Teune TM. Parotid metastasis from a gastroesophageal carcinoma: report of a case. Dig Surg. 2007; 24: 68-9. PMid:17369685. http://dx.doi.org/10.1159/000100922

[8] Dangore-Khasbage SB, Degwekar SS, Bhowate RR, et al. Metastatic involvement of parotid from carcinoma of the breast-a case report. Oral Maxillofac Surg. 2009; 13: 49-53. PMid:19190940. http://dx.doi.org/10.1007/s10006-009-0146-8

[9] Ando K, Masumoto N, Sakamoto M, et al. Parotid gland metastasis of breast cancer: case report and review of the literature. Breast Care. 2011; 6: 471-3. PMid:22419903. http://dx.doi.org/10.1159 1000335222
[10] Joyce MR, Awad ZT, Saleem T, et al. The parotid gland: an unusual site of metastasis from carcinoma of breast. Ir J Med Sci. 2000 JulSep; 169(3): 230. PMid:11245139. http://dx.doi.org/10.10 07/BF03167708

[11] Spreafico R, Nicoletti G, Ferrario F, et al. Parotid metastasis from renal cell carcinoma: a case report and review of the literature. Acta Otorhinolaryngol Ital. 2008; 28: 266-8. PMid:19186459.

[12] Wiesel JM, Weshler Z, Sherman Y, et al. Parotid gland metastatic carcinoma of breast origin. J Surg Oncol. 1982 Aug; 20(4): 227-30. PMid:7109626. http://dx.doi.org/10.1002/jso. 293020040 8

[13] Duncan M, Monteiro M, Quante M. Bilateral parotid gland metastases from carcinoma of the breast that presented 25 years after initial treatment. Br J Oral Maxillofac Surg. 2015 Jan; 53(1): 94 6. PMid:25451071. http://dx.doi.org/10.1016/j.bjoms.2 014.09 .023

[14] Zhang JZ, Gu M. Malignant phyllodes tumor of the breast metastatic to the parotid gland diagnosed by fine needle aspiration biopsy-A case report. Acta Cytol. 2003 Mar-Apr; 47(2): 253-8. PMid:12685197. http://dx.doi.org/10.1159/000326512

[15] Alath P, Kapila K, Hussein S, et al. Parotid gland metastasis of breast cancer diagnosed on fine needle aspiration cytology: case report and review of literature. Cytopathology. 2014; 25: 346-8. PMid:24138676.

[16] Demir Y, Surucu E, Durak MG, et al. Contralateral parotideal lymph node metastasis detected by PET/CT in a female patient with locally advanced breast cancer. Rev Esp Med Nucl Imagen Mol. 2013 SepOct; 32(5): 330-1. PMid:23290831. http://dx.doi.org/10.10 $16 /$ j.remn. 2012.11.004

[17] Sellinger M, Neubauer K, William M, et al. Contralateral metastasis of parotid gland in advanced breast cancer with peripheral facial paralysis. Arch Gynecol Obstet. 2011; 284: 1557-60. PMid:21822624. http://dx.doi.org/10.1007/s00404-011-1989-4

[18] Shimoyama T, Horie N, Yamada T, et al. Parotid lymph node metastasis from adenocarcinoma of the urachus. Dentomaxillofac Radiol 2000; 29: 185-8. PMid:10849547. http://dx.doi.org/10.1038 /sj.dmfr. 4600525 